\title{
Evaluation of the effects of prespinal administration of Ondansetron on maternal hemodynamics
}

\author{
Arivumani $\mathbf{T ~ A}^{1}$, Arul Anne Rose $\mathbf{S}^{2}$, Ushadevi $\mathbf{G}^{3}$ \\ ${ }^{1}$ Dr. Arivumani T A, Assistant Professor, Department of Anaesthesia, ${ }^{2}$ Dr. Arul Anne Rose S, Associate Professor, \\ Department of Obstetrics and Gynaecology, ${ }^{3}$ Dr.Ushadevi G, Professor, Department of Obstetrics and Gynaecology. All \\ are affiliated to Tagore Medical College and Hospital, Rathinamangalam, Chennai, India.
}

Address for Correspondence: Dr. Arul Anne Rose S, Associate Professor, Department of Obstetrics and Gynaecology, Tagore Medical College and Hospital, Rathinamangalam, Chennai -127, phone No- E-mail: annejoan04@gmail.com

\begin{abstract}
Introduction: Spinal anaesthesia is the preferred method of anaesthesia for elective lower segment caesarean section (LSCS). It has a shorter onset time, but is associated with hypotension and bradycardia, which at times may be deleterious to both mother and fetus. Aim of Study: To evaluate the effects of intravenous administration of ondansetron prior to spinal anaesthesia on the hemodynamic responses in the mother specifically hypotension and bradycardia. Materials and Methods: The study was a hospital based prospective, double-blinded, randomized, placebo controlled study in our teaching medical college and hospital over a period of 6 months -February to July 2015. As per inclusion and exclusion criteria of our study, study population (72 patients) was identified who were planned for elective LSCS. They were randomly allocated into two groups. 5 minutes prior to spinal anaesthesia, group $\mathrm{O}(\mathrm{n}=36)$ received $4 \mathrm{mg}$ IV Ondansetron and group $\mathrm{P}(\mathrm{n}=36)$ received physiological saline. Blood pressure and heart rate were monitored once in 5 minutes for 30 minutes, and requirement of vasopressors was noted. Results: Hypotension was significantly lower in group O when compared to group P. Bradycardia was less in number in group $\mathrm{O}$ but it was statistically insignificant. Vasopressor requirement was also lower in group $\mathrm{O}$ patients.Conclusion: Intravenous Ondansetron $4 \mathrm{mg}$ given 5 minutes prior to spinal anaesthesia significantly reduces the hypotension. The episodes of bradycardia as well as the requirement of vasopressors in parturients were low in ondansetron group, which was found to be statistically insignificant, may be due to less number of study population.
\end{abstract}

Keywords: Ondansetron, Spinal anaesthesia, LSCS, Hypotension, Bradycardia

\section{Introduction}

Spinal anaesthesia causing subarachnoid block is the preferred method of anaesthesia for elective LSCS. Spinal anaesthesia for LSCS is beneficial due to simplicity of technique, faster administration, rapid onset of anaesthesia, decreased risk of systemic toxic effects and increased density of block [1]. Maternal hypotension is one of the important complications that occur during intraoperative period following spinal anaesthesia with an incidence of about 50-80\% [2]. Occassionally, in very severe cases, it may cause adverse effects on mother like loss of consciousness and

Manuscript received $3^{\text {rd }}$ April 2016

Reviewed: $15^{\text {th }}$ April 2016

Author Corrected: $24^{\text {th }}$ April 2016

Accepted for Publication $4^{\text {th }}$ May 2016 pulmonary aspiration, and on neonates like hypoxia, acidosis and neurological injuries $[3,4]$.

Hence, many preventive measures are used to prevent hypotension including left uterine displacement, prophylactic ephedrine, crystalloid or colloid preloading and using compression stockings on the lower limbs [4]. Ondansetron, now days is emerging as an effective alternative for the prevention of spinal induced hypotension in elective LSCS patients. It is a 5HT 3 (5 Hydroxy tryptamine) receptor antagonist, which inhibits Bezold - Jarisch reflex (BJ reflex). Maternal hypotension following spinal anaesthesia is due to sympathetic nerve blockade which inturn decreases 
blood return to the heart. Bezold -Jarisch reflex is mediated by serotonin receptors within the wall of the ventricle in a response to falling blood pressure.These receptors, belong to 5 HT 3 subtype and cause an increased efferent vagal signaling when bound by serotonin released during hypovolemic conditions, clinically leading to bradycardia and further hypotension $[5,6]$.

Ondansteron, a widely used anti emetic to prevent nausea and vomiting induced by cancer chemotherapy, radio therapy and surgery $[7,8]$.It is a category $\mathrm{B}$ drug, safe to use during pregnancy $[9,10]$. The mechanism of action is serotonin antagonism, blocking $5 \mathrm{HT}$ from activated platelets to 5 HT 3 receptors [11-13], then alleviates the BJ reflex triggered by $5 \mathrm{HT}$ and inhibits peripheral vasodilatation and increases blood return to the heart $[6,11]$.

The aim of the study is to evaluate the effects of intravenous administration of ondansetron prior to spinal anaesthesia on the hemodynamic responses in the mother specifically hypotension and bradycardia.

\section{Materials and Methods}

The study was conducted after getting permission from Institutional Ethical Committee. A detailed informed consent was obtained from the patients. The study was a hospital based prospective, double - blinded, randomized, placebo controlled study in our teaching medical college and hospital over a period of 6 months February to July 2015. The study population was selected from the patients who were electively posted for LSCS during our study period using inclusion and exclusion criteria of our study.

\section{Inclusion criteria}

Elective lower segment Caesarean section at term with singleton baby

Age 18-35 years

ASA II

Booking BMI 20-30

\section{Exclusion criteria}

$\mathrm{H} / \mathrm{O}$ allergy to Ondansetron

Coagulopathies

Severely altered spine anatomy

Existing neurological deficits

Hypertensive disorders

Infections at spinal injection site.
Totally 72 patients were selected as study population and randomly assigned to two groups namely, group $\mathrm{P}$ $(n=36)$ - Placebo group and group $\mathrm{O}(\mathrm{n}=36)$ Ondansetron group. Ondansetron diluted in $5 \mathrm{ml}$ saline and $5 \mathrm{ml}$ physiological saline were prepared by an anaesthetist who was blinded to the study. Baseline systolic blood pressure( SBP), diastolic blood pressure (DBP), mean arterial blood pressure ( MAP, MAP = $(\mathrm{SBP}+2 \mathrm{X} \mathrm{DBP}) / 3)$, heart rate $(\mathrm{HR})$ were measured at 2 minutes interval using a noninvasive Electrocardiography monitor.

Three recordings were taken before anaesthesia after a silent resting period of 5 minutes. Average MAP and HR were calculated and taken as a baseline value of that particular patient. A standard 16-gauge venflon was placed in one of the superficial veins of forearm; warm ringer lactate was infused according to patient's weight. 5 minutes before spinal anaesthesia, $5 \mathrm{ml}$ of physiological saline was injected to placebo group and $5 \mathrm{ml}$ of diluted Ondansetron (diluted in physiological saline) to Ondansetron group. The anaesthetist injecting the drug and monitoring the vital parameters was blinded to the study.

Then spinal anaesthesia was performed by standard lumbar puncture in sitting position, at the level of L3L4 or L4 -L5 using a Quincke's, 25 gauge spinal needle, $2 \mathrm{ml}$ of $0.5 \%$ of hyperbaric bupivacaine was injected intrathecally.

Immediately after injection, patients were laid supine with left lateral uterine displacement. After 2 minutes of intra thecal injection of bupivacaine MAP, HR were measured, and there after every 5 minutes for 30 minutes. 5 minutes after spinal anaesthesia, block plane was assessed by needle puncture method. Every 5 minutes the height of peak block was assessed. Hypotension was defined as MAP drop > 20\% from baseline value and bradycardia as $\mathrm{HR}<50$ beats/ min. Recordings were noted down and it was planned to give IV Ephedrine 6mg if MAP dropped to $<60 \mathrm{mmHg}$ and IV Atropine if $\mathrm{HR}<40 / \mathrm{min}$. 5 IU Oxytocin was given IM after delivery and IV fluids were given according to weight.

The outcomes measured were baseline MAP, episodes of hypotension, bradycardia and need of vasopressors. The data were subjected to Chi square test and Fisher's Exact Test with SPSS software version 20.0. 


\section{Results}

All 72 patients who were enrolled in the study, completed the study. All the spinal blocks were successful with achievement of satisfactory level of anaesthesia. Out of 36 patients in placebo group, 21 patients (58.3\%) had hypotension and out of 36 patients in Ondansetron group, 11 patients $(30.6 \%)$ had hypotension.

When comparing the results of both groups, using Pearson Chi-Square test, the occurrence of hypotension was significantly lower in Ondansetron $(\mathrm{p}=0.018)$ group. $(\mathrm{p}<0.05)$ [Table Ia, Ib].

Table-Ia: Incidence of hypotension in study population.

\begin{tabular}{|c|c|c|c|c|c|}
\hline \multicolumn{6}{|c|}{ Group $(\mathbf{O} / \mathbf{P}) *$ Hypotension Cross tabulation } \\
\hline & & & \multicolumn{2}{|c|}{ Hypotension } & \multirow[t]{2}{*}{ Total } \\
\hline & & & YES & NO & \\
\hline \multirow[t]{4}{*}{ group ( $\mathrm{O} / \mathrm{P})$} & \multirow[t]{2}{*}{ Ondansetron } & Count & 11 & 25 & 36 \\
\hline & & $\%$ within group $(\mathrm{O} / \mathrm{P})$ & $30.6 \%$ & $69.4 \%$ & $100.0 \%$ \\
\hline & \multirow[t]{2}{*}{ Placebo } & Count & 21 & 15 & 36 \\
\hline & & $\%$ within group $(\mathrm{O} / \mathrm{P})$ & $58.3 \%$ & $41.7 \%$ & $100.0 \%$ \\
\hline
\end{tabular}

Table-Ib: Incidence of hypotension in study population.

\begin{tabular}{|c|c|c|c|c|c|}
\hline \multicolumn{6}{|l|}{ Chi-Square Tests } \\
\hline & Value & df & $\begin{array}{l}\text { Asymp. Sig. } \\
\text { (2-sided) }\end{array}$ & $\begin{array}{l}\text { Exact Sig. } \\
\text { (2-sided) }\end{array}$ & $\begin{array}{l}\text { Exact Sig. } \\
\text { (1-sided) }\end{array}$ \\
\hline Pearson Chi-Square & $5.625^{\mathrm{a}}$ & 1 & .018 & & \\
\hline Continuity Correction $^{b}$ & 4.556 & 1 & .033 & & \\
\hline Likelihood Ratio & 5.705 & 1 & .017 & & \\
\hline Fisher's Exact Test & & & & .032 & .016 \\
\hline $\begin{array}{l}\text { Linear-by-Linear } \\
\text { Association }\end{array}$ & 5.547 & 1 & .019 & & \\
\hline $\mathrm{N}$ of Valid Cases & 72 & & & & \\
\hline
\end{tabular}

a. 0 cells $(0.0 \%)$ have expected count less than 5 . The minimum expected count is 16.00 .

b. Computed only for a $2 \times 2$ table

On analysing the heart rate changes in both the groups, in placebo group out of 36 pts, bradycardia was noted in 4 patients $(11.1 \%)$ while none from the ondansetron group had bradycardia. This was found to be significant using ChiSquare test $(\mathrm{p}<0.05)$ but since the numbers were small, we had to use Fisher's Exact Test where it was not found to be statistically significant. ( $\mathrm{p}=0.115)$ [Table IIa, b]

Table IIa: Incidence of bradycardia in study population.

\begin{tabular}{|c|c|c|c|c|c|}
\hline \multicolumn{6}{|c|}{$\operatorname{group}(\mathbf{O} / \mathbf{P}) *$ Bradycardia Cross tabulation } \\
\hline & & & \multicolumn{2}{|c|}{ Bradycardia } & \multirow[t]{2}{*}{ Total } \\
\hline & & & YES & NO & \\
\hline \multirow[t]{4}{*}{ group $(\mathrm{O} / \mathrm{P})$} & \multirow[t]{2}{*}{ Ondansetron } & Count & 0 & 36 & 36 \\
\hline & & $\%$ within group $(\mathrm{O} / \mathrm{P})$ & $0.0 \%$ & $100.0 \%$ & $100.0 \%$ \\
\hline & \multirow[t]{2}{*}{ Placebo } & Count & 4 & 32 & 36 \\
\hline & & $\%$ within group $(\mathrm{O} / \mathrm{P})$ & $11.1 \%$ & $88.9 \%$ & $100.0 \%$ \\
\hline
\end{tabular}


Table IIb: Incidence of bradycardia in study population.

\begin{tabular}{|c|c|c|c|c|c|}
\hline \multicolumn{6}{|l|}{ Chi-Square Tests } \\
\hline & Value & df & $\begin{array}{l}\text { Asymp. Sig. } \\
\text { (2-sided) }\end{array}$ & $\begin{array}{l}\text { Exact Sig. (2- } \\
\text { sided) }\end{array}$ & $\begin{array}{l}\text { Exact Sig. (1- } \\
\text { sided) }\end{array}$ \\
\hline Pearson Chi-Square & $4.235^{\mathrm{a}}$ & 1 & .040 & & \\
\hline Continuity Correction $^{\mathrm{b}}$ & 2.382 & 1 & .123 & & \\
\hline Likelihood Ratio & 5.781 & 1 & .016 & & \\
\hline Fisher's Exact Test & & & & .115 & .057 \\
\hline $\begin{array}{l}\text { Linear-by-Linear } \\
\text { Association }\end{array}$ & 4.176 & 1 & .041 & & \\
\hline $\mathrm{N}$ of Valid Cases & 72 & & & & \\
\hline
\end{tabular}

a. 2 cells $(50.0 \%)$ have expected count less than 5 . The minimum expected count is 2.00 .

b. Computed only for a $2 \times 2$ table

Vasopressor (ephedrine) was used only for six patients in placebo group who had MAP < 60mmHg. In patients who developed bradycardia (seen only in placebo group) as HR was within 41-50/ min, Atropine was not used. Postpartum period was uneventful for all mothers and neonates.

\section{Discussion}

Spinal anaesthesia is a method of introducing anaesthetic drugs into subarachnoid space to temporarily abolish the motor and sensory functions of group of spinal nerves. Maternal hypotension is one of the important complications that occur during intraoperative period following spinal anaesthesia with an incidence of about $50-80 \%$ [2].

In parturients, supine position required for LSCS is associated with fall in BP due to aortocaval compression by the pregnant uterus in $8 \%$ of the patients, even without spinal anaesthesia.During LSCS, combined factors like supine position causing aortocaval compression, peripheral vasodilatation caused by spinal anaesthesia can lead to hypotension and bradycardia which inturn causes uteroplacental insufficiency, fetal hypoxia and acidosis [14,15]. Studies have reported that in few patients it may lead to dangerous effects, including cardiac arrest, thought it is a result of progressive bradycardia rather than progressive hypotension $[16,17]$.

Various methods are used to reduce the incidence of hypotension and bradycardia like preloading with intravenous fluids, positioning the patients in such a way that it facilitates venous return and administration of vasopressors. Another method is to use prophylactic administration of pharmacologic agents like Ondansetron, which may be more effective than hydration [5, 6, 16-18].
Ondansetron significantly reduced the need of vasopressor in Ondansetron patients, which was very important finding in pregnant women because in pregnant women administration of vasoconstrictors can have adverse effects on uterine blood flow. Few earlier studies explained that IV Ondansetron might antagonise the sensory block of intrathecal local anaesthetics. It could be a potential explanation for attenuation of hemodynamic changes following spinal anaesthesia [19-23]. Hypotension without bradycardia following spinal anaesthesia may be explained by the predominance of parasympathetic over sympathetic tone [24].

The most important observation in our study is that IV Ondansetron (4mg) to the patient prior to spinal blockade may help prevent hypotension.Out of 36 patients in placebo group, 21 patients (58.3\%) had hypotension and in Ondansetron group, 11(30.6\%) had hypotension. The difference was statistically significant. When we analyse the occurrence of bradycardia, it was $11.1 \%$ in the placebo group compared to $0 \%$ in the Ondansetron group, but due to the less number of patients in the study, the statistical significance could not be proved. Further studies with more number of patients are required to study whether Ondansetron decreases the incidence of bradycardia. As there was no case of severe bradycardia $(<40 / \mathrm{min})$ in our study, vasopressor was not used. 
According to Owczuk R et al, Ondansetron attenuated the decrease in MAP but did not have an influence on HR compared to control saline group [25].It was similar to our study except the dose of Ondansetron used was 8 $\mathrm{mg}$ in their study, which was $4 \mathrm{mg}$ in our study.In a study by Meng Wang et al, they have concluded that the incidence of maternal hypotension was significantly lower in group of patients who received 4 and $6 \mathrm{mg}$ of Ondansetron when compared to group of patients who received saline, $2 \mathrm{mg}$ and $8 \mathrm{mg}$ of ondansetron [26].

In a study by Sahoo et al, they have concluded that IV Ondansetron reduced the hypotensive episodes and vasopressor requirements [27] which also supports our study results.

\section{Conclusion}

Administration of intravenous Ondansetron 4mg prior to spinal anaesthesia in planned LSCS patients reduces the episodes of hypotension, bradycardia and vasopressor requirement.By doing so, it alleviates the deleterious consequences of hypotension, bradycardia and the side effects of administration of vasopressors in the mother and the baby.

Funding: Nil, Conflict of interest: None initiated. Permission from IRB: Yes

\section{References}

1. Kar W Ng, Jacqueline Parsons, Allan M Cyna, Philippa Middleton. Spinal versus epidural anaesthesia for caesarean section. pub2/ abstract. retrieved on 23.6.11

2. Stewart A, Fernando R, Mc Donald S, Hignett R, Jones T, Columb M. The dose - dependent effects of phenylephrine for elective cesarean delivery under spinal anaesthesia. Anesth Analg. 2010 Nov; 111(5): 1230- 37. doi: 10.1213/ANE.0b013e3181f2eae1. Epub 2010 Sep 14.

3. Reynolds F, Seed PT. Anaesthesia for Caesarean section and neonatal acid-base status: a meta-analysis. Anaesthesia. $2005 \mathrm{Jul} ; 60(7): 636-53$.

4. Cyna AM, Andrew M, Emmett RS, Middleton P, Simmons SW. Techniques for preventing hypotension during spinal anaesthesia for caesarean section. Cochrane Database Syst Rev. 2006 Oct 18;(4): CD 002251
5. Campagna JA, Carter C. Clinical relevance of the Bezold-Jarisch reflex. Anesthesiology. 2003 May; 98(5) : 1250-60.

6. Aviado DM, Guevara Aviado D. The Bezold-Jarisch reflex. A historical perspective of cardiopulmonary reflexes. Ann N Y Acad Sci. 2001 Jun;940:48-58.

7. Christofaki M, Papaioannou A. Ondansetron: a review of pharmacokinetics and clinical experience in postoperative nausea and vomiting. Expert Opin Drug Metab Toxicol. 2014 Mar; 10(3):437-44. doi: 10. 1517/ 17425255.2014.882317. Epub 2014 Jan 28.

8. Yeh YC, McDonnell A, Klinger E, Fowler B, Matta L, Voit D, Reddy P. Comparison of healthcare resource use between patients receiving ondansetron or palonosetron as prophylaxis for chemotherapy-induced nausea and vomiting. J Oncol Pharm Pract. 2011 Sep;17(3):179-85. doi: 10.1177/1078155210366491. Epub 2010 May 7.

9. Tucker ML, Jackson MR, Scales MD, Spurling NW, Tweats DJ, Capel-Edwards K. Ondansetron: pre-clinical safety evaluation. Eur J Cancer Clin Oncol. 1989;25 Suppl 1:S79-93.

10. Adrienne Einarson, Caroline Maltepe, Yvette Navioz, Deborah Kennedy, Michael Paul Tan, Gideon Koren. The saftey of ondansetron for nausea and vomiting of pregnancy: a prospective comparative study. BJOG.2004 Sep; vol 111 pp. 940-43. DOI: $10.1111 /$ j.1471-0528.2004.00236.x

11. Martinek RM.Witnessed asystole during spinal anesthesia treated with atropine and ondansetron: a case report. Can J Anaesth. 2004 Mar;51(3):226-30.

12. Gyermek L. Pharmacology of serotonin as related to anesthesia. J Clin Anesth. 1996 Aug;8(5):402-25.

13. Mao HZ, Li Z, Chapleau MW. Platelet activation in carotid sinuses triggers reflex sympathoinhibition and hypotension. Hypertension. 1996 Mar;27(3 Pt 2):58490.

14. Kinsella SM, Lohmann G. Supine hypotensive syndrome. Obstet Gynecol. 1994 May;83(5 Pt 1):77488.

15. S.W.Y.Lee, K.S.Khaw, W.D.Ngan Kee, T.Y.Leung and L.A.H.Critchley. Haemodynamic effects from 
aortocaval compression at different angles of lateral tilt in non-labouring term pregnant women. British Journal of Anaesthesia 2012; 109(6): 950-6 doi: 10. 1093/ bja/ aes/ 349.

16. Mark AL. The Bezold- Jarisch reflex revisited clinical implication of inhibitory reflexes originating in the heart. J Am Coll Cardiol. 1983; 1(1): 90-102.

17. Yamano M, Kamato T, Nishida A, Ito H, Yuki H, Tsutsumi R, Honda K, Miyata K. Serotonin (5-HT)3receptor antagonism of 4,5,6,7-tetrahydrobenzimidazole derivatives against 5-HT-induced bradycardia in anesthetized rats. Jpn J Pharmacol. 1994 Jul;65(3):2418 .

18. Kinsella SM, Tuckey JP. Perioperative bradycardia and asystole: relationship to vasovagal syncope and the Bezold-Jarisch reflex. Br J Anaesth. 2001 Jun; 86 (6) :859-68.

19. Fassoulaki A, Melemeni A, Zotou M, Sarantopoulos C. Systemic ondansetron antagonizes the sensory block produced by intrathecal lidocaine. Anesth Analg. 2005 Jun;100(6):1817-21.

20. Hessami MA, Yari M. Granisetron versus dexamethasone in prophylaxis of nausea and vomiting after laparoscopic cholecystectomy. Anesth Pain Med. 2012 Fall;2(2):81-4. doi: 10.5812/aapm.6945. Epub 2012 Sep 13.

21. Jabbary Moghaddam M, Ommi D, Mirkheshti A, Dabbagh A, Memary E, Sadeghi A, et al. Effects of clonidine premedication upon postoperative shivering and recovery time in patients with and without opium addiction after elective leg fracture surgeries. Anesth Pain Med.2013; 2(3):107-10. doi:10.5812/aapm.7143.

22. Golfam P, Yari M, Bakhtiyari HR. Minimum appropriate dose of lidocaine with a fixed dose of sufentanil epinephrine used for spinal anesthesia in caesarian section. Anesth Pain Med. 2013 Winter;2(3):123-6. doi: 10.5812/aapm.7810. Epub 2013 Jan 1.

23. Fathi M, Imani F, Joudi M, Goodarzi V. Comparison Between the Effects of Ringer's Lactate and Hydroxyethyl Starch on Hemodynamic Parameters After Spinal Anesthesia: A Randomized Clinical Trial. Anesth Pain Med.2013 Winter; 2(3):127-33. doi: 10.5812/aapm.7850

24. Marashi SM, Soltani-Omid S, Soltani Mohammadi S, Aghajani Y, Movafegh A. Comparing Two Different Doses of Intravenous Ondansetron With Placebo on Attenuation of Spinal-induced Hypotension and Shivering. Anesth Pain Med. 2014 Mar 18;4(2):e12055. doi: 10.5812/aapm.12055. eCollection 2014.

25. Owczuk R, Wenski W, Polak- Krzeminska A, Twardowski P, Arszulowicz R, Dylczyk- Sommer A, et al. Ondansetron given intravenously attenuates arterial blood pressure drop due to spinal anesthesia: a doubleblind, placebo- controlled study. Reg Anesth Pain Med. 2008 Jul-Aug;33(4):332-9. doi: 10.1016/j. rapm. 2008.01.010.

26. Meng Wang, LangZhuo, Qun Wang, Ming-Kun Shen, Yan- Yun Yu, Jun- Jing Yu, Zhi, Ping Wang. Efficacy of prophylactic intravenous ondansetron on the prevention of hypotension during cesarean delivery: a dose- dependent study. Int J Clin Exp Med 2014; 7(12):5210-16

27. Sahoo T, Sen Dasgupta C, Goswami A, Hazra A. Reduction in spinal -induced in Hypotension with ondansetron in parturients undergoing caesarean section: a double- blind randomised, placebo-controlled study. Int J Obstet Anesth. 2012 Jan;21(1):24-8. doi: 10.1016/j.ijoa.2011.08.002. Epub 2011 Nov 18.

\section{How to cite this article?}

Arivumani T A, Arul Anne Rose S, Ushadevi G. Evaluation of the effects of prespinal administration of Ondansetron on maternal hemodynamics. Int J Med Res Rev 2016;4(5):689-694.doi: 10.17511/ijmrr.2016.i05.04. 